\title{
THE DEVELOPMENT OF SPECIFIC FORMS OF TOURISM IN MOSTAR AND WEST HERZEGOVINIAN TOURIST-GEOGRAPHICAL REGIONS
}

\author{
Aida Bidžan ${ }^{1}$ \\ Haris Gekić
}

\begin{abstract}
Mostar and West Herzegovinian tourist-geographical regions are rich in natural and anthropogenic tourist potentials, where specific forms of tourism can be developed, such as: mountain, hunting, rural, excursion-recreational, adventure, recreational/sports, fishing, speleological, ecotourism, religious, cultural manifestation, business, convention and transit tourism. This paper will present the main natural and geographical and socio-geographical characteristics of tourist-geographical regions, as well as the possibility of their valorisation for the development of tourism in them. Moreover, it will present the tourist trade and accommodation capacities of these tourist and geographic regions. In this paper, the following methods will be applied: statistical, valorisation, descriptive, cartographic, etc.
\end{abstract}

Key words: Mostar, West Herzegovina, tourist-geographical region, tourism development

\section{INTRODUCTION}

In preparing the plan for tourist-geographical regionalization, the method of tourist valorization was used, in which the following criteria was used: natural and anthropogenic tourist attractions, transport infrastructure, tourism traffic, catering and accommodation capacity, scope and quality of the tourism offer, tradition and recognition in the tourism market, human resources, complementarity and competition with the environment, and as parameters: the average value of tourist arrivals and ratings of tourist products of Bosnia and Herzegovina municipalities. After analyzing all of the criteria and parameters, using data from the Statistical Offices of Bosnia and Herzegovina, units set aside with common tourism products, and those units we called tourist-geographical regions of Bosnia and Herzegovina.

According to the common tourist characteristics there has been set aside 13 touristgeographical regions: Sarajevo, Tuzla, Posavina, Podrinje, Bihać, Banja Luka, Mostar, east Herzegovinian, west Herzegovinian, southwest Bosnian, Coastal, Travnik and Doboj. According to its functionality, they are divided into three groups: metropolitan, leisure area and the areas - cognitive, educational and religious (Bidžan, 2011). In this paper we will present the third group of regions - cognitive, educational and religious, and according to their tourist potentials, they include the following tourist-geographical regions: Mostar and West Herzegovinian, and we will show more specific forms of tourism that can be developed in these tourist potentials.

\footnotetext{
${ }^{1}$ Department of Geography, Faculty of Science, University of Sarajevo, Sarajevo, Bosnia and Herzegovina, e-mail:aidabidzan@gmail.com.

${ }^{2}$ Department of Geography, Faculty of Science, University of Sarajevo, Sarajevo, Bosnia and Herzegovina, e-mail: hgekic@gmail.com.
} 


\section{MOSTAR TOURIST-GEOGRAPHICAL REGION}

Mostar tourist-geographical region covers an area of 3,225 $\mathrm{km}^{2}$, from Makljen and Ivansedlo in the north to Mostar field in the south. Tourist-geographical position of this region is very favorable because the significant Bosnian and Herzegovinian road M-17 passes through it, which connects the capital of Bosnia and Herzegovina and the tourist center of the region to the Adriatic coast. Its position will further improve once the highway Vc is built, and tourists who are to come to the capital will come easier and visit also this area.

Mostar tourist-geographical area consists of 5 municipalities: Jablanica, Konjic, Mostar, East Mostar and Prozor. This region according to preliminary data from the census of 2013 has 166,987 inhabitants, and the population density is 51.7 persons per $\mathrm{km}^{2}$.

The tourist center of this region is Mostar who is also a political, economic, financial and cultural center of Herzegovina. The unique beauty of the region is contained in that it is at the same time mountainous and lowland, and coastal and continental. In the areas around Jablanica, Konjic and Prozor are rich bio-geographic and hydrographic tourist potentials, which are preserved from anthropogenic pollution. In Table 1 we will show the most important natural and anthropogenic tourist potentials and specific forms of tourism which can grow on them in this tourist-geographical area.

The natural characteristics of this region are very diverse with colorful richness of landscapes, especially its forest areas that represent the geo-ecologically preserved area with natural attractions of the region, such as the endemic Bosnian pine, various species of mushrooms and herbs, various karst formations, numerous springs, waterfalls, attractive localities of the Neretva canyon, Rakitnica and Drežanka, etc.

Special attention that it deserves was given to the mountain river Neretva which provides a unique experience in one its parts with adrenaline-filled rafters in the canyon upstream from Konjic. Track length for rafting on the Neretva from Glavatičevo to Konjic is about $23 \mathrm{~km}$ with the beautiful canyons and waterfalls which can be seen on the descent. In the upper course, from Glavatičevo to Bjelimići, there is a kind of air spa which is very well visited throughout the year. The opening of the fishing season on the Neretva river takes place on the first of April and closes on the first of November. Being rich in fish, it is quite visited by anglers from all over the territory of Bosnia and Herzegovina. In the lower flow of the river Neretva where rafting ends in the village Džajići, $4 \mathrm{~km}$ from Konjic, there is a beach which is visited during the summer season. This river provides the following development of specific forms of tourism: bathing, fishing, sports and recreational, adventure and excursion tourism.

Moreover, noteworthy is the Nature Park Blidinje whose live sceneries are Blidinje lake, the high mountain depression Dugo polje, mountains Čvrsnica and Vran, occupies $358 \mathrm{~km}^{2}$ and is located in the northwestern part of macroregion. Blidinje, a natural pearl with a lot of diversity in a small area, offers excellent opportunities for the development of the following specific types of tourism: winter-sports, rural, eco-tourism and mountain tourism. 
Tab. 1: Most important natural tourism potentials in Mostar tourist-geographical region

\begin{tabular}{|c|c|c|c|}
\hline \multicolumn{3}{|c|}{ Natural tourism potentials } & Specific \\
\hline \multirow{13}{*}{ Geomorphological } & \multirow{8}{*}{ Mountains } & Vran & MT, HT, \\
\hline & & Ljubuša & MT, HT, \\
\hline & & Raduša & MT, HT, \\
\hline & & Prenj & MT, HT, \\
\hline & & Čvrsnica & MT, HT, \\
\hline & & Bjelašnica & MT, HT, \\
\hline & & Bitovnja & MT, HT, \\
\hline & & Velež & MT, HT, \\
\hline & \multirow[b]{2}{*}{ Glens and canyons } & Canyon of Neretva & TR, FT, \\
\hline & & Canyon of Doljanka & TR, FT, \\
\hline & \multirow{3}{*}{ Caves and pits } & Cave Ševrljica near Blagaj & ST \\
\hline & & $\begin{array}{l}\text { Cave Vrpeć in Odžak - } \\
\text { Bjelimići near Konjic }\end{array}$ & ST \\
\hline & & Green cave above Blagaj & ST \\
\hline \multirow{15}{*}{ Hidrographical } & \multirow{8}{*}{ Rivers } & Neretva & TR, FT, \\
\hline & & Drežanjka & TR, FT, \\
\hline & & Rodobolja & TR, FT, \\
\hline & & Buna & TR, FT, \\
\hline & & Bunica & TR, FT, \\
\hline & & Trebižat & TR, FT, \\
\hline & & Bregava & TR, FT, \\
\hline & & Doljanka & TR, FT, \\
\hline & Springs & Buna Spring & TR \\
\hline & \multirow[b]{2}{*}{ Waterfalls and riffles } & Waterfall Šištice & $\mathrm{TR}$ \\
\hline & & Waterfall on Bregava river & TR \\
\hline & \multirow{4}{*}{ Lakes } & Jablaničko lake & SRT, TR \\
\hline & & Boračko lake & SRT, TR \\
\hline & & Ramsko lake & SRT, TR \\
\hline & & Blidinje lake & SRT, TR \\
\hline \multirow[b]{2}{*}{ Climatical } & Mountain climate & Prenj, Velež & MT, HT, \\
\hline & $\begin{array}{c}\text { Modified } \\
\text { meditererranean }\end{array}$ & Konjic, Mostar & $\begin{array}{l}\text { CT, BT, } \\
\text { RT, }\end{array}$ \\
\hline
\end{tabular}

Source: Bidžan, 2011

Legend: MT- mountain tourism; HT - hunting tourism; RT - rural tourism; TR - triprecreational tourism; ET - extreme tourism; SRT- sports-recreational tourism; FT fishing tourism; ST - speleological tourism; ECOT - ecotourism; CT - cultural tourism; $B T$ - business tourism; CGT - congress tourism; TT - transit tourism. 
Tab. 2: Most important anthropoghenic tourism potentials in Mostar tourist-geographical region

\begin{tabular}{|c|c|c|c|}
\hline \multicolumn{3}{|c|}{ Anthropoghenic tourism potentials } & $\begin{array}{c}\text { Specific forms } \\
\text { of tourism }\end{array}$ \\
\hline \multirow{2}{*}{ Archaeological } & \multirow{2}{*}{$\begin{array}{l}\text { Numerous necropolis } \\
\text { with medieval } \\
\text { tombstones (stećak) }\end{array}$} & Visočica & $\mathrm{CT}, \mathrm{TR}$ \\
\hline & & Konjic & $\mathrm{CT}, \mathrm{TR}$ \\
\hline \multirow{22}{*}{$\begin{array}{l}\text { Architectural } \\
\text { heritage }\end{array}$} & \multirow[b]{2}{*}{ Fortress } & Počiteljska & $\mathrm{CT}$ \\
\hline & & Stjepan town - Blagaj & $\mathrm{CT}$ \\
\hline & \multirow{4}{*}{ Bridges } & Lekina ćuprija - Blagaj & $\mathrm{CT}$ \\
\hline & & Kriva ćuprija - Mostar & $\mathrm{CT}$ \\
\hline & & Stara ćuprija - Konjic & $\mathrm{CT}$ \\
\hline & & Old Bridge - Mostar & CT \\
\hline & \multirow{8}{*}{ Buildings } & Česma on Musala - & $\mathrm{CT}$ \\
\hline & & Kujundžiluk čaršija - & CT \\
\hline & & Sahat tower - Prozor & $\mathrm{CT}$ \\
\hline & & Old town Počitelj & CT, TT \\
\hline & & Bishop castle - Mostar & $\mathrm{CT}$ \\
\hline & & Gymnasium - Mostar & $\mathrm{CT}$ \\
\hline & & City hamam - Mostar & $\mathrm{CT}$ \\
\hline & & Kajtaz house & CT \\
\hline & \multirow{5}{*}{ Sacral objects } & $\begin{array}{c}\text { Franciscan monastery and } \\
\text { church Uznesenja Blažene } \\
\text { Djevice Marije, Šćit }\end{array}$ & CT \\
\hline & & Old orthodox church, & $\mathrm{CT}$ \\
\hline & & Karađoz-beg mosque, & CT \\
\hline & & $\begin{array}{l}\text { Koski Mehmed-paša } \\
\text { mosque. Mostar }\end{array}$ & CT \\
\hline & & $\begin{array}{l}\text { Cathedral of Mother } \\
\text { Marv Mostar }\end{array}$ & CT \\
\hline & \multirow{3}{*}{$\begin{array}{l}\text { Memorial centres } \\
\text { and objects }\end{array}$} & Jablanica & $\mathrm{CT}$ \\
\hline & & Uzdoljani - Rama & CT \\
\hline & & Drežnica - Mostar & $\mathrm{CT}$ \\
\hline \multirow{3}{*}{$\begin{array}{l}\text { Museums, galleries } \\
\text { and collections }\end{array}$} & \multicolumn{2}{|c|}{ Museum of Herzegovina, Mostar } & CT \\
\hline & \multicolumn{2}{|c|}{ Old Bridge Museum, Mostar } & $\mathrm{CT}$ \\
\hline & \multicolumn{2}{|c|}{ Collection of wood-carving products "Mulić } & CT \\
\hline \multirow[t]{5}{*}{ Manifestations } & \multicolumn{2}{|c|}{ Mostar Summer } & $\mathrm{CT}$ \\
\hline & \multicolumn{2}{|c|}{ Buna Mevlud } & $\mathrm{CT}$ \\
\hline & \multicolumn{2}{|c|}{ International business fair, Mostar } & CT, BT \\
\hline & \multicolumn{2}{|c|}{ Jumps from Old Bridge, Mostar } & CT \\
\hline & \multicolumn{2}{|c|}{ Jump into Kazan, Konjic } & $\mathrm{CT}$ \\
\hline Cultural heritage & \multicolumn{2}{|c|}{ Monument of mitraistic cult - Konjic } & CT \\
\hline
\end{tabular}




\begin{tabular}{|l|c|c|}
\hline Religious $\begin{array}{c}\text { Cernički Sibjan mekteb } \\
\text { educational instit. }\end{array}$ & Ćejvan ćehajin mekteb & CT \\
\cline { 2 - 3 } & Mostar & CT \\
\hline \multirow{4}{*}{ Municipalities } & & CT, BT, RT, \\
& CGT, TT, \\
& ECOT, RGT, \\
\cline { 2 - 3 } & Konjic & CT, RT, TT, \\
\cline { 2 - 3 } & Jablanica & CT, TT, SRT \\
\cline { 2 - 3 } & Prozor & CT, ECOT, \\
& & RT, SRT, RGT \\
\hline
\end{tabular}

Source: Bidžan, 2011

Legend: RGT - religious tourism; RT - rural tourism; SRT- sports-recreational tourism; ST - speleological tourism; ECOT - ecotourism; CT - cultural tourism; BT - business tourism; CGT - congress tourism; TT-transit tourism.

We will single out one anthropogenic tourism potential and that is Dovište Buna, near Mostar, where once upon a time gathered Bogomils, it is one of the major pilgrimage sites in Bosnia and Herzegovina, whose number of visitors from all neighboring countries, as well as remote Emirates often exceeds the figure of 40,000. Therefore, this is a big event which is prepared and implemented by the organizers of this event, in which a central role is played by Dani Mevluda (Days of Mawlid), where Bosniaks traditionally gather to celebrate Mawlid, the birth of the Prophet (peace and blessings of Allah be upon him). In any case, it is one of the most beautiful customs of the traditional gathering of Bosniaks (Table 2).

All pilgrimage sites in Bosnia and Herzegovina are considered to be a certain phenomenon, unknown in other countries with a majority of Muslim population. It speaks only of the uniqueness of Bosniaks as a nation. Traditional Mawlid (Mevlud) and Dhikr (Zikr) are held on the second Saturday in May every year. Mawlid has been held in Blagaj since 1975 with a four-year interruption during the war (1992-1995). According to tourism workers, the most common foreign guests in Blagaj are tourists from Malaysia and Turkey. The guests from Turkey are well informed and fascinated by the fact that the Tekke (Tekija) was built by the order of the Ottoman sultan, who was left spellbound by the beauty of this place. Tekke is open for visitors throughout the year, and in the garden overlooking the spring of the river Buna, tourists can have the original Turkish coffee, tea or a refreshing drink.

Konjic is situated on the Neretva river, $60 \mathrm{~km}$ from Sarajevo, just down Jablanica lake. Konjic and surroundings are attractive for tourists in both summer and winter. There are fishing on the Neretva, the Rakitnica, Boračko and Jablanica lake, hunting on the mountain Prenj, Visočica and Bitovnja, and above all famous culinary specialties. Boračko lake is approximately $20 \mathrm{~km}$ far from the city center. It is a beautiful, natural lake, good for swimming, rest and recreation, rich in a variety of fish, and is a paradise for anglers. On the wealth of natural and anthropogenic tourist potentials, this municipality can develop the following forms of tourism: cultural and manifestation, fishing, hunting, bathing, mountain, adventure, eco-tourism, excursion tourism, transit, rural, and so on. 
In the municipality of Prozor - Rama, in Šćit, there is one of the oldest Franciscan monasteries in Bosnia and Herzegovina, which is an attractive tourist destination due to its turbulent history and artistic value, and there is also beautiful Ramsko lake which is rich in fish, and is also a paradise for anglers. This municipality can develop the following specific forms of tourism: bathing, fishing, eco-tourism, rural, cultural and manifestation.

Mostar, the political, financial and cultural center of this tourist-geographical region, is located at the foot of the slopes of the mountains Velež, Hum and Cabulja, in the valley of the Neretva River, at an altitude of 60-80 m. It is a city of sun, greenery, blossom which is characterized by pleasant Mediterranean climate with long hot summers. Mostar is $60 \mathrm{~km}$ far from the sea, and in it and its vicinity there are many unique sites of cultural and historical treasure and heritage witnessing the life in this area since the ancient times. Mostar has a complete spatial infrastructure, road and rail traffic that goes from north to south to the Adriatic Sea, and a modern airport. Mostar is first mentioned in 1452. Up until the Ottoman conquest in 1468, Mostar was considered for the small and insignificant place. The name of the city of Mostar was first mentioned in documents from 1469. Among the explanations of the origin of name the most interesting are two: Mostar was named after bridge keepers and after two towers which were called mostars. The city grew and soon became the center of Herzegovina. Even before 1592, Mostar was the center of the Mufti (muftije); in 1767 it became the center of the Herzegovinian Metropolit, and since the half of the last century it has been the center of the Catholic bishop. The Old City of Mostar is interesting for its lively narrow streets. It contains a multitude of restaurants and traditional crafts. There is also a multitude of cultural and historical and religious sites such as the Old Bridge, the Crooked Bridge (Kriva ćuprija), Tabačica, Koski Mehmed Pasha Mosque, the Hammam, and so on. Moreover, it is important to mention sports and tourist event - Dives from the old bridge, which is probably one of the most famous events in the environment. Divers symbolize courage, boldness and a healthy lifestyle. The green Neretva, the biggest river in Herzegovina symbolizes purity of nature, while the Old Bridge tells the story about the history, architecture and people of this region. This event is always accompanied by a large number of tourists from Bosnia and Herzegovina and the region. This municipality can develop the following specific forms of tourism: cultural and manifestation, bathing, sports and recreation, and religious and fishing tourism.

Mostar tourist-geographic area is connected over the main roads M-17 (E73) to Sarajevo region and the Adriatic coast, over the main road M-16.2 to Travnik region and the regional road R-419 (Jablanica-Posušje) or to west Hercegovinian region and with the Republic of Croatia, which is in part still a gravel road. Through this area runs the modern type railway Sarajevo-Mostar-Ploče (the Republic of Croatia). The city of Mostar has an international airport which is of great importance for the future development of tourism in this region.

As for the tourist traffic, Mostar tourist-geographical area in 2014 had 800,000 tourist arrivals, of which domestic tourists accounted for $32 \%$ and foreign tourists $68 \%$. They had 140,292 nights of which domestic participated with $24 \%$, and foreign tourists with $76 \%$. Most tourists come from Croatia, Turkey, Italy, Slovenia, Serbia, Montenegro, Germany, Spain and France (http://www.fzs.ba/Podaci/07.pdf). As for accommodation capacities, this region offers 16,372 beds in various types and categories of accommodation (hotels, motels, small pensions, private houses, etc.) with the increasing tendency of tourist 
capacities and a significant annual growth in revenue. There is a very well developed cottage industry, and small inns, restaurants and cellars offer visitors the unforgettable taste of the Orient and Mediterranean.

This tourist-geographical region is of great importance to define the tourist offer of Bosnia and Herzegovina; of the total 626 national monuments in Bosnia and Herzegovina, in the area of Mostar region there are the 64 national monuments. Its unique natural and anthropogenic tourist potentials enable the development of a number of specific forms of tourism: bathing, sports and recreational, adventure, religious, educational, cultural and manifestation, etc.

\section{WEST HERZEGOVINIAN TOURIST-GEOGRAPHICAL REGION}

West Herzegovinian tourist-geographical area, as its name suggests, is located in the western part of Herzegovina. Tourist-geographic location is very convenient because it is located only $30 \mathrm{~km}$ from the Adriatic coast and on the border between our country and the Republic of Croatia, which also increases the importance of its position. Its municipalities are the following: Čitluk, Ljubuški, Grude, Široki Brijeg and Posušje with an area of 1,544 $\mathrm{km}^{2}$. The tourist center of this region is the municipality of Čitluk. According to preliminary data from the 2013 census, there is a population of 97,893 people and population density is 63.4 persons per $\mathrm{km}^{2}$. The most important geomorphological potentials are the mountains: Vran, Čvrsnica and Čabulja, the fields: Mostar Blato, Posuško, Šuićko, Ljubuško and Grudsko, as well as numerous waterfalls and caves, and the nature park Blidinje. Hydrographic tourist potentials are also very specific and among them stand out the underground river Trebižat and its waterfall Kravice. Biogeographically, this area is characterized by the following ecosystems: Bosnian pine forest (Pinus heldreichii) and thermophilic deciduous forests with Turkey oak (Table 3).

Tab. 3: Most important natural tourism potentials in West Herzegovina touristgeographical region

\begin{tabular}{|c|c|c|c|}
\hline \multicolumn{3}{|c|}{ Natural tourism potentials } & \multirow{2}{*}{$\begin{array}{c}\begin{array}{c}\text { Specific forms } \\
\text { of tourism }\end{array} \\
\text { MT, HT, TR }\end{array}$} \\
\hline Geomorphological & Mountains & Čvrsnica & \\
\hline & & Čabulja & $\mathrm{MT}, \mathrm{HT}, \mathrm{TR}$ \\
\hline \multirow[t]{5}{*}{ Hidrographical } & Rivers & Vrljika-Matica-Tihaljina- & TR, RT, SRT \\
\hline & \multirow{3}{*}{$\begin{array}{l}\text { Waterfalls and } \\
\text { riffles }\end{array}$} & Bučine & TR \\
\hline & & Kočuša & TR \\
\hline & & Kravica & TR \\
\hline & Lakes & Blidinje lake & TR, SRT \\
\hline \multirow[t]{2}{*}{ Climatic } & $\begin{array}{c}\text { Modified } \\
\text { meditererranean } \\
\text { climate }\end{array}$ & Široki Brijeg & $\begin{array}{l}\text { MT, HT,TR, } \\
\text { SRT }\end{array}$ \\
\hline & $\begin{array}{c}\text { Meditererranean } \\
\text { climate }\end{array}$ & Ljubuški & TR, SRT \\
\hline
\end{tabular}

Source: Bidžan, 2011 
Legend: MT- mountain tourism; HT - hunting tourism; RT - rural tourism; TR - triprecreational tourism; ET - extreme tourism; SRT- sports-recreational tourism; FT fishing tourism; ST - speleological tourism; ECOT-ecotourism; CT - cultural tourism; BT-business tourism; CGT-congress tourism; TT-transit tourism.

Wine and tobacco are the crops with which generations have grown up and lived off. Nowadays in Brotnjo one can enjoy a splash of high quality wine from autochthonous varieties of Žilavka and Blatina and thus feel the union of nature, tradition and quality. Their qualities are witnessed by the Charter of Ban Kulin from 1353, which in the famous Čitluk document speaks of quality wine from this region (http://www.Hercegovina.ba/hrv/brotnjo.html).

In the municipality of Čitluk today is registered 20 odd wineries, and each of them in its own way distributes quality wine across Europe which has been proven by valuable prizes in numerous exhibitions throughout Eastern Europe. One of the phenomena of viticulture in Brotnjo are also stone vineyards that represent a real tourist attraction. Vineyards of stone, with the help of sunlight and water from the Neretva, produce high quality stone wine (Table 4).

Tab. 4: Most important anthropoghenic tourism potentials in West Herzegovina touristgeographical region

\begin{tabular}{|c|c|c|c|}
\hline \multicolumn{3}{|c|}{ Anthropoghenic tourism potentials } & \multirow{2}{*}{$\begin{array}{c}\begin{array}{c}\text { Specific forms of } \\
\text { tourism }\end{array} \\
\mathrm{CT}, \mathrm{TR}, \mathrm{ET} \\
\end{array}$} \\
\hline \multirow[t]{2}{*}{ Archaeological } & \multirow{2}{*}{$\begin{array}{c}\text { Numerous } \\
\text { necropolis with } \\
\text { medieval } \\
\text { tombstones } \\
\text { (stećak) }\end{array}$} & Blidinje & \\
\hline & & $\begin{array}{l}\text { Mramorje, Gornji } \\
\text { Studenci, Ljubuški }\end{array}$ & $\mathrm{CT}, \mathrm{TR}$ \\
\hline \multirow[t]{10}{*}{$\begin{array}{l}\text { Architectural } \\
\text { heritage }\end{array}$} & Fortress & $\begin{array}{l}\text { Tower of Herceg } \\
\text { Stjepan, Ljubuški }\end{array}$ & $\mathrm{CT}$ \\
\hline & \multirow{3}{*}{ Buildings } & Marića Gaj, Grude & CT \\
\hline & & Winery in Ljubuški & CT, ET \\
\hline & & $\begin{array}{l}\text { Eco-ethno village } \\
\text { "Herceg", Međugorje }\end{array}$ & CT \\
\hline & \multirow[t]{6}{*}{ Sacral objects } & $\begin{array}{c}\text { Church Bezgrešno začeće } \\
\text { Blažene Djevice Marije, } \\
\text { Posušie }\end{array}$ & CT, RGT \\
\hline & & $\begin{array}{c}\text { Church Uznesenja } \\
\text { Blažene Djevice Marije, }\end{array}$ & CT, RGT \\
\hline & & $\begin{array}{c}\text { Church St. Ivan } \\
\text { Nepomuka, Posušje }\end{array}$ & CT, RGT \\
\hline & & $\begin{array}{c}\text { Church st. Mihovil, } \\
\text { Cruda }\end{array}$ & CT, RGT \\
\hline & & $\begin{array}{c}\text { Franciscan monastery } \\
\text { with church, Šroki Brijeg }\end{array}$ & CT, RGT \\
\hline & & $\begin{array}{l}\text { Nesuh-aga Vučjaković } \\
\text { mosque, Ljubuški }\end{array}$ & CT, RGT \\
\hline
\end{tabular}




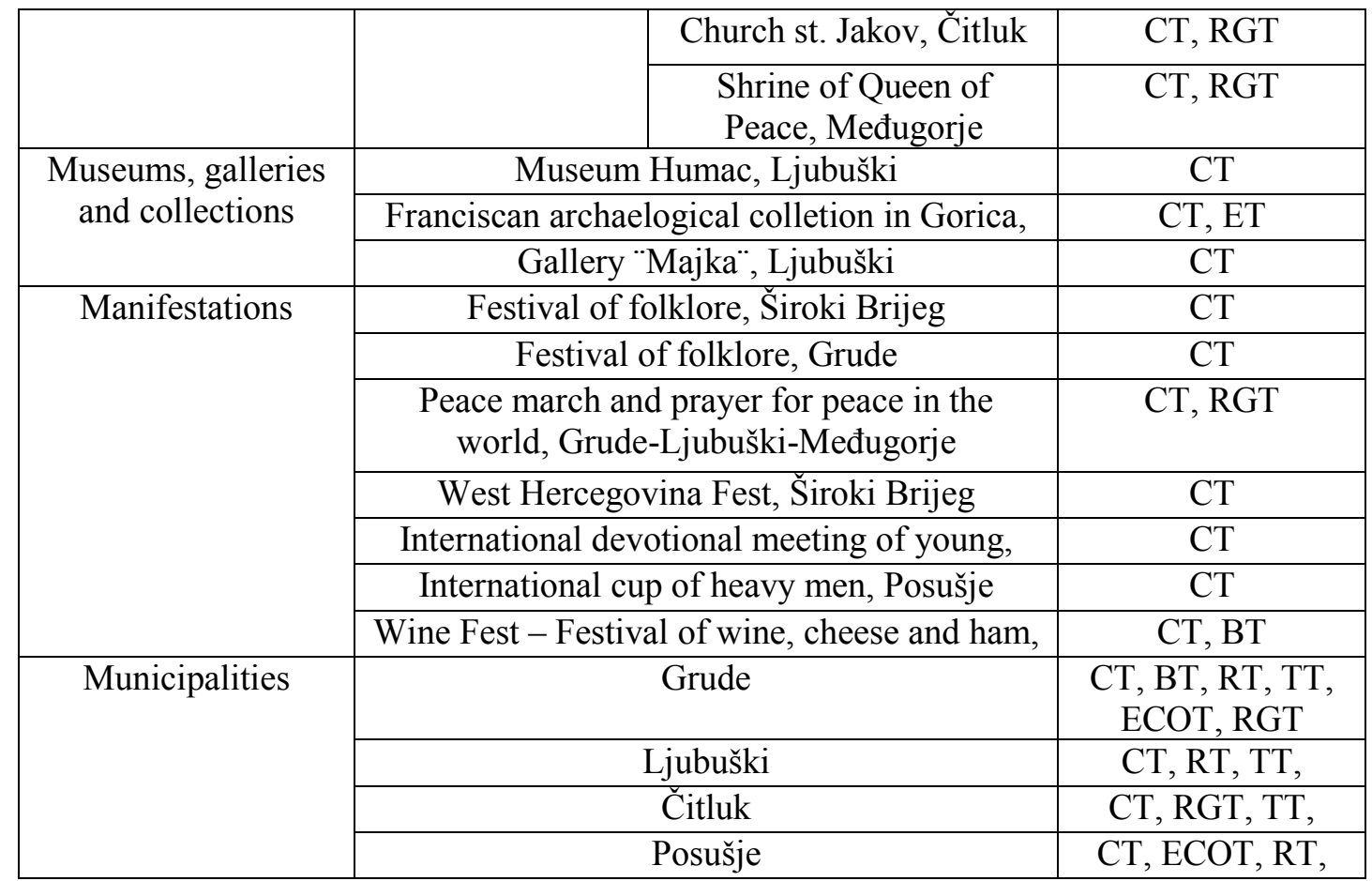

Source: Bidžan, 2011

Legend: RGT - religious tourism; RT - rural tourism; SRT- sports-recreational tourism; ST - speleological tourism; ECOT - ecotourism; CT - cultural tourism; BT - business tourism; CGT - congress tourism; TT-transit tourism; ET - educational tourism.

Stone wineyards are located in Blizanci and they were planted 26 years ago in an area of 100 hectares. The locality of Blizanci is unique in that the stone desert was turned into an oasis of abundance and beauty. Assuming that the personality of the wine is largely conditioned by the character of the ambience - the stone on which the grapes are produced, the manufacturer of the wine called it "Stone" and, as such, it began to be produced in 1990. Brotnjo boasts of the fact that in Gradnići is the oldest wine cellar in Bosnia and Herzegovina which was built in 1855 by the parish priest Fr. Petar Bakula.

Today, this cellar is a tourist attraction based on which we can show the time in which life of the people of Brotnjo took place in the time of the Ottomans. With the aim of promoting Brotnjo as a wine region, in 2006 started the project "Vinska cesta Hercegovine" (Herzegovinian wine route). Through this project, the image of Herzegovina was created, which positively promote this area in Europe and the world. Each year, in honor of the grape harvest, cultural economic and tourist event "Dani berbe grožđa” (Vintage days) in Čitluk is held in September. No matter what, Brotnjo is a place that will treat every guest with top quality wine and in which each guest will feel the combination of nature, tradition and quality of this fertile region (www.vinskacesta.ba/index.php).

Moreover, it is important to note that by the arrival to this region, especially in Međugorje (Medjugorje), you will feel peace and beauty of life, harmony of a man and nature. Međugorje today is one of the most visited pilgrimage sites (shrines) in the whole Catholic 
world. In the village of Bijakovići in the area of Međugorje, according to the testimony of six children, Our Lady has been appearing every day since 24 June 1981. Following the interest of pilgrims from around the world for visit to Međugorje, there were built large tourist facilities. Hence, Međugorje has about 10,000 beds in various categories of accommodation with high-quality restaurants, shopping and other service facilities. Since then, thousands and thousands of pilgrims come to Međugorje from all over the world and so far it has been, according to general estimates, visited by more than 15 million pilgrims, far more from abroad than from the country.

According to the tourist representatives and news correspondents around the world, Međugorje has become the best known and most often mentioned place in this part of Europe. By apparition of the Queen of Peace, Međugorje has developed tourism and has become an inevitable destination with a rich religious prayer content for millions of pilgrims from all over the world.

Throughout the year, numerous seminars and festivals are held in Međugorje, among them, we must highlight the Youth Festival that has been held for the past 20 years in Međugorje. The Youth Festival is held every year in the first days of August and during it Međugorje becomes the world center of youth from which messages of peace, love and faith are sent to the world. The most important events throughout the year are: Apparition, Youth festival, Assumption of the Virgin Mary, Mass on Križevac, Easter, Christmas and New Year. The pilgrims who come to Međugorje besides an inevitable visit to the Apparition Hill and Križevac, in the sanctuary have an opportunity to visit several more interesting destinations (http://www.hercegovina.ba/hrv/medjugorje.html) (Fig.1).

West Herzegovinian tourist-geographical region is linked to southwest Bosnia region by highway M-15, and to the region of Mostar by highway M-6.1, while it is linked to the Coastal region by the highway M-6. As for the tourist traffic, West Hecegovinian touristgeographical region in 2014 had the number of tourist arrivals of 3972, of which domestic tourists accounted for $34.3 \%$, and foreign tourists 65,7\%. They had 5,916 nights of which domestic tourists participated with 33\%, and foreign tourists with 77\%. Most tourists come from the Croatia, Italy, Slovenia, Germany, Serbia and Montenegro (http://www.fzs.ba/Podaci/08.pdf).

As for the accommodation, this area offers 205 beds in various types and categories of accommodation (hotels, motels, small hotels, private houses and other) which is a very small number and must be urgently increased if this tourist-geographical area wants to seriously engage in tourism. It has a very modest importance for defining the tourist offer of Bosnia and Herzegovina, out of the total of 626 national monuments in Bosnia and Herzegovina, in its area are 19 national monuments. It can develop the following specific forms of tourism: cultural and manifestation, mountain, eco tourism, rural, educational, speleologic, sports and recreation and others.

\section{CONCLUSION}

Mostar and West Herzegovinian tourist-geographical regions have ideal natural and anthropogenic tourist potentials for the development of many specific forms of tourism. Religious tourism can be developed in Međugorje, Mostar, Blagaj, Prusac, Travnik and Fojnica, where there are numerous religious buildings of various confessions which host 
numerous religious events: Youth festival in Međugorje, Dani Ajvatovica in Prusac, Mawlid in Buna, etc. Intact geomorphological and hydrographic tourist potentials such as: Vlašić, Rostov, Neretva, Vrbas, Nature Park Blidnje lake, and many others allow it to develop different types of sports and recreational tourism: winter-sports, bathing, fishing, hunting, rafting, cycling, paragliding, mountain climbing, etc. Moreover, these touristgeographical regions have numerous authentic villages in which rural tourism could be developed by the engagement of tourist boards and local people, which would certainly contribute to the revitalization of these villages once again and young people would remain living in these regions and providing financial security on the doorstep. All listed specific forms could more intensly begin developing in these tourist-geographical regions, only if tourist boards and local governments would make an effort, and that would further contribute to more balanced regional development of these regions.

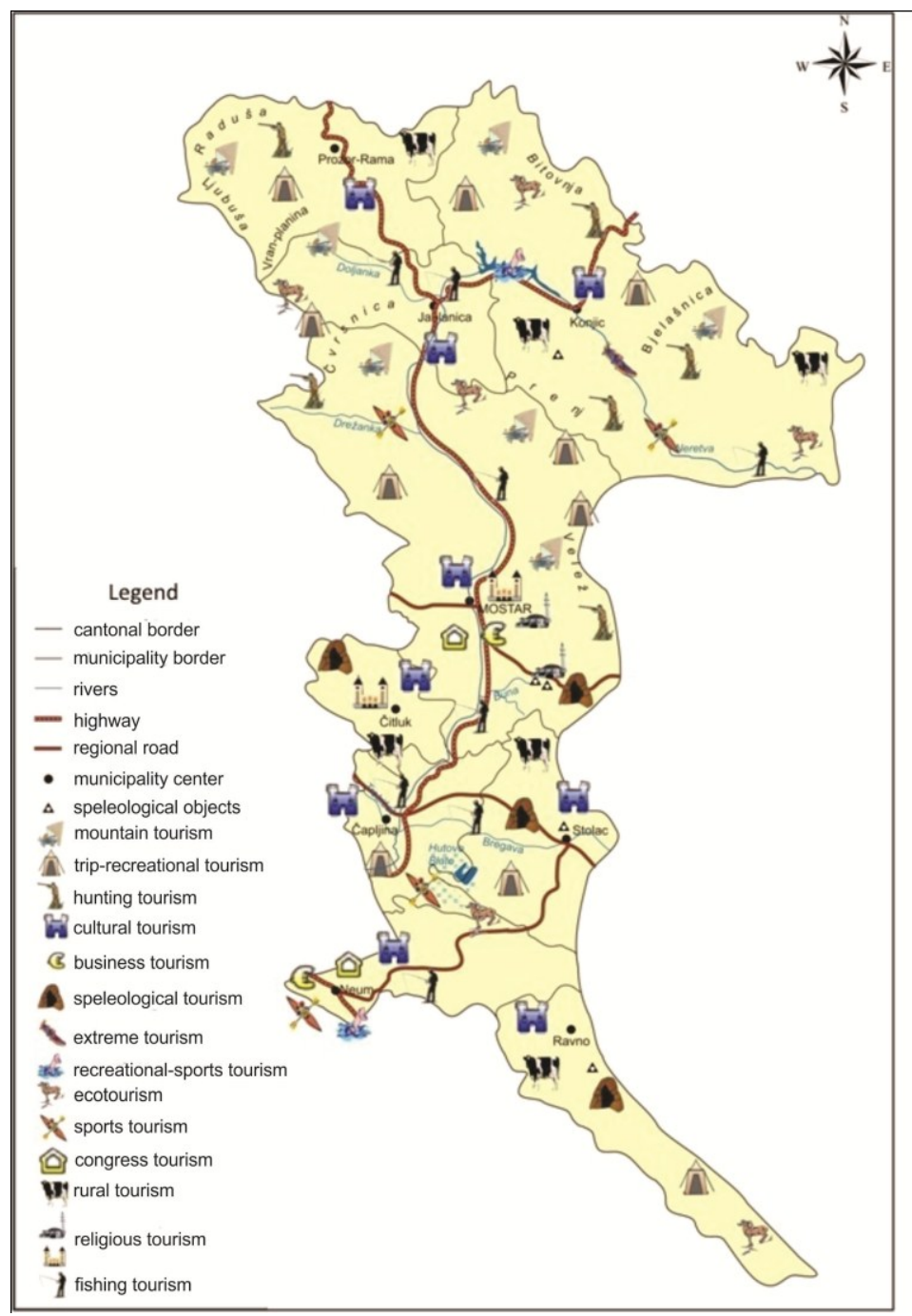

Fig.1. Specific forms of tourism in Mostar and West Herzegovinian tourist-geographical regions 


\section{REFERENCES:}

1.Bidžan, A. (2011): Turističko-geografsko rejoniranje kao osnova geografske regionalizacije Bosne i Hercegovine, Magistarski rad odbranjen na Prirodnomatematičkom fakultetu Univerziteta u Sarajevu, Sarajevo.

2.Odluke o proglašenju dobara nacionalnim spomenicima, i privremena lista nacionalnih spomenika Bosne i Hercegovine, Komisija za očuvanje nacionalnih spomenika Bosne i Hercegovine.

3.Prostorni plan Bosne i Hercegovine, Faza "B" - valorizacija; Prirodne i kulturnohistorijske vrijednosti, Institut za arhitekturu, urbanizam i prostorno planiranje Arhitektonskog fakulteta u Sarajevu, Sarajevo, 1980.

4.Strategija razvoja turizma Federacije Bosne i Hercegovine 2008 - 2018., Federalno ministarstvo okoliša i turizma, Sarajevo, 2008.

5.Strategija razvitka općine Grude za razdoblje do 2015. godine, Općina Grude, Grude, 2007.

6.Turistički master plan općine Ljubuški, Institut za turizam, Zagreb, 2010.

7.http://www.hercegovina.ba/index.php/bs/ (15.11.2014)

8.http://www.zeleni-neretva.ba/pdf/Zastita\%20prirode_web.pdf (16.10.2014.)

9.http://www.bhtourism.ba/loc/hercegovina.wbsp (11.06.2015)

10.http://www.turizam.mostar.ba/index.php?lang=en (12.07.2015.)

11.http://www.tz-sirokibrijeg.com/Turizam.htm (11.03.2015)

12.http://www.visithercegovina.com/index.php/zupanija-zzh/ljubuski (22.08.2015.)

13.http://www.visithercegovina.com/index.php/zupanija-zzh/posusje (24.08.2015.)

14.http://www.fzs.ba/Podaci/07.pdf (10.09.2015.)

15.http://www.Hercegovina.ba/hrv/brotnjo.html (10.09.2015.)

16.http://www.fzs.ba/Podaci/08.pdf (10.09.2015.)

17.http://www.vinskacesta.ba/index.php (11.09.2014) 